\title{
PROGRESIFITAS PUTUSAN MAHKAMAH KONSTITUSI REPUBLIK INDONESIA TENTANG PERSELISIHAN HASIL PEMILIHAN UMUM KEPALA DAERAH
}

\author{
Oleh: \\ Karlinae D. Bangas \\ Fakultas Hukum Universitas Palangka Raya
}

\begin{abstract}
Abstrak:
Kewenangan dari Mahkamah Konstitusi Republik Indonesia berdasarkan UUD NKRI Tahun 1945 serta Undang-Undang Mahkamah Konstitusi antara lain memutus perselisihan tentang hasil pemilihan umum termasuk didalamnya adalah perselisihan hasil pemilihan kepala daerah. Adapun yang dimaksud dengan perselisihan hasil adalah perselisihan terkait dengan hasil penghitungan suara pasca/setelah pemilihan. Mahkamah berpendapat bahwa tidak boleh ada pihak yang diuntungkan dalam perolehan suara akibat terjadinya pelanggaran konstitusi dan prinsip keadilan dalam penyelengaraan Pemilu termasuk Pemilukada, yang harus dilakukan secara demokratis dan tidak melanggar asas-asas pemilihan umum yaitu langsung, umum, bebas, rahasia, jujur dan adil. Penyelesaian sengketa PHPUKada yang dilakukan oleh Mahkamah Konstitusi merupakan suatu solusi yang dianggap mampu menyelesaikan persoalan hasil pemilihan umum dan pemilihan umum kepala daerah, mengingat persoalan sengketa PHPU merupakan salah satu kewenangan yang dimiliki oleh Mahkamah Konstitusi sebagaimana diatur dalam UUD NKRI Pasal 24 C serta pada Undang-Undang Mahkamah Konstitusi. Metode yang digunakan adalah metode penelitan yuridis normatif. Tujuan dari penelitian ini adalah mengetahui kewenangan Mahkamah Konstitusi dalam memutuskan perselisihan hasil Pemilihan Umum Kepala Daerah dalam perspektif hukum progresif. Progresifnya tindakan Mahkamah Konstitusi dinilai sebagai sebuah terobosan baru yang sangat positif dalam perkembangan sistem hukum di Indonesia untuk menangkis anggapan yang selama ini bahwa hakim hanyalah dianggap sebagai corong undang-undang.
\end{abstract}

Kata kunci : Progresifitas, Putusan, Mahkamah Konstitusi.

\section{Abstract:}

The Constitutional Court of the Republic of Indonesia's authority is based on the 1945 Constitution of the Republic of Indonesia and the Constitutional Court Law, among others, to decide on disputes over general election results, including disputes over regional head election results. Referred to as a resulting dispute is a dispute related to the post-election vote count results. The Court believes that no party should benefit from the votes acquired as a result of violations of the constitution and the principles of justice in the administration of the General Election, including the Regional Head General Election, which must be conducted democratically and not violate the principles of general elections, namely direct, general, free, secret, honest and fair. The PHPUKada dispute resolution carried out by the Constitutional Court is a solution that is considered capable of resolving the issue of the results of general elections and regional head elections, considering that the dispute over PHPU is one of the powers that the Constitutional Court has as stipulated in Article 24C of the Indonesian Constitution and the Law Constitutional Court Law. The method used is a normative juridical research method. The purpose of this research is to determine the authority of the Constitutional Court in deciding disputes over the results of the Regional Head General Election in a progressive legal perspective. The Constitutional Court's 
progressive action is considered a new, very positive breakthrough in the development of the legal system in Indonesia to fend off the presumption that judges are only seen as mouthpieces of law.

Keywords: Progressiveness, Verdict, Constitutional Court.

\section{PENDAHULUAN}

Semenjak bergulirnya amandemen (perubahan) konstitusi (Undang-Undang Dasar Negara Republik Indonesia) dari Negara Kesatuan Republik Indonesia (NKRI) yang di mulai pada tahun 1999 sampai dengan tahun 2002, tampak beberapa badan dan lembaga negara mengalami perubahan (penambahan dan pengurangan jumlah, susunan dan kedudukannya). Perubahan tersebut diantaranya berupa nomenklatur maupun kewenangan masing-masing. Alasan utama dari perubahan konstitusi adalah kebutuhan negara yang semakin mendesak dalam roda penyelenggaraan negara. Pada perubahan konstitusi tersebut salah satu lembaga yang dibentuk adalah Mahkamah Konstitusi Republik Indonesia (MKRI). MKRI didesain dan untuk menjadi pengawal dan sekaligus penafsir terhadap UndangUndang Dasar melalui putusanputusannya.

Sebagai upaya dalam menjalankan fungsi dan kewenangan konstitusionalnya, MKRI berupaya mewujudkan visi tegaknya konstitusi dalam rangka mewujudkan cita negara hukum dan demokrasi demi kehidupan kebangsaan dan kenegaraan yang bermartabat. Visi tersebut menjadi pedoman bagi MKRI dalam menjalankan kekuasaan kehakiman secara bebas, merdeka, tanpa intervensi dari pihak manapun dan bertanggungjawab sesuai amanat konstitusi.

Eksistensi dari MKRI sejak kehadirannya pada tahun 2003 dinilai cukup signifikan dan berkonstribusi menjaga hukum dan mengembangkan demokrasi di Indonesia. Keberadaan dan peran dari MKRI tidak lepas dari fakta mengenai uji materi Undang-Undang terhadap Undang-Undang Dasar (judicial review), yang sejatinya merupakan kewenangan paling utama dan fundamental dari MKRI. Selain itu judicial review merupakan perkara yang paling sering disidangkan di persidangan MKRI.

Mahkamah Konstitusi Republik Indonesia sebagai lembaga negara pengawal dan penafsir konstitusi yang keputusannya bersifat final dan mengikat menurut sebagian pengamat hukum 
hingga saat ini telah menjalankan fungsinya dengan baik, MKRI merupakan garda terakhir dalam menjaga konstitusionalitas suatu undang-undang. Banyak sekali dari sekian putusan MKRI yang mendapat apresiasi tinggi dari masyarakat tidak terkecuali dari pakar hukum seperti Satjipto Rahardjo. Ia menyatakan kita sungguh bersalah manakala menyinggung putusan MKRI itu hanya disinggung secara sepintas. Mungkin kita perlu mendirikan monumen agar orang selalu mengingat bahwa pada suatu hari dalam sejarahnya, Indonesia pernah memiliki pengadilan yang bekerja dengan penuh kehormatan, turut merasakan penderitaan bangsanya dan menyelamatkan bangsa dari situasi yang gawat (Rahardjo, 2010).

Pada beberapa putusannya MKRI sering membuat terobosan hukum yang progresif dengan pertimbangan substansi hukum tidak hanya pertimbangan prosedural. Putusan Mahkamah Konstitusi yang bersifat progresif artinya tidak hanya keadilan prosedural yang dilakukan akan tetapi lebih mementingkan keadilan substansial. Salah satu contoh adalah pembatalan hasil pemilihan umum kepala daerah (PEMILUKADA) di Kabupaten Kotawaringin Barat beberapa tahun yang lalu, banyak pihak yang menyebutkan putusan Mahkamah Konstitusi tersebut berlebihan atau diluar kewenangan. Mahkamah Konstitusi menurut undangundang hanya memutus sengketa hasil pemilihan umum (Pemilu), sedangkan penentuan pemilu ulang apalagi menetapkan pemenang adalah wewenang Komisi Pemilihan Umum (KPU) bukan Mahkamah Konstitusi. Ketua Mahkamah Konstitusi waktu itu Mahfud MD menyatakan bahwa Mahkamah Konstitusi tidak boleh terbelenggu atau terpenjara oleh undang-undang, sedangkan di depan mata ada ketidakadilan (kecurangan). Terobosan- terobosan hukum yang dilakukan Mahkamah Konstitusi dalam membuat putusan merupakan bentuk hukum yang progresif atau implementasi dari penegakan hukum progresif.

Secara teoritis gagasan hukum progresif bertolak dari dua komponen basis dalam hukum, yaitu peraturan dan perilaku (rules and behavior). Disini, hukum ditempatkan sebagai aspek perilaku namun juga sekaligus sebagai peraturan. Peraturan akan membangun suatu sistem hukum positif, sedangkan perilaku atau manusia akan menggerakkan peraturan dan sistem yang telah (akan) terbangun itu. Mahkamah Konstitusi kemudian mengembangkan 
suatu paradigma baru dalam menangani sengketa pilkada yang tidak semata-mata terpaku pada aspek kuantitatif, yakni angka-angka hasil penghitungan suara melainkan juga pada aspek kualitatif pemilhan umum yang LUBERJURDIL (M. M. Ali et al., 2016).

Metode penelitian yang digunakan dalam penulisan ini adalah penelitian yuridis normatif, yaitu penelitian hukum yang meletakan hukum sebagai sebuah bangunan sistem norma. Sistem norma yang dimaksud adalah mengenai asasasas, norma, kaidah dari peraturan perundang-undangan.Tujuan dari penelitian ini adalah untuk mengetahui kewenangan Mahkamah Konstitusi dalam memutuskan perselisihan hasil Pemilihan Umum Kepala Daerah dalam perspektif hukum progresif.

\section{PEMBAHASAN}

Mahkamah Konstitusi Republik Indonesia (MKRI) merupakan satusatunya kekuasaan kehakiman yang memiliki putusan bersifat final dan mengikat (final and binding). Dalam hal ini, dapat dikategorikan ke dalam 2 (dua) garis besar, yakni putusan Mahkamah Konstitusi yang menimbulkan akibat hukum yang bermakna positif dan akibat hukum yang bermakna negatif. Adapun akibat hukum yang bermakna positif, yaitu: Mengakhiri suatu sengketa hukum; Menjaga prinsip checks and balances; dan Mendorong terjadinya proses politik. Sedangkan akibat hukum yang bermakna negatif, yaitu: Tertutupnya akses upaya hukum dan terjadinya kekosongan hukum. Dalam suatu putusannya MKRI menilai bahwa setiap pelanggaran ini akan menjadi ukuran yang dipakai oleh Mahkamah Konstitusi untuk membatalkan hasil PEMILUKADA apabila terbukti adanya pelanggaran yang bersifat terstruktur, sistematis dan massif (M. Ali, 2016). Menurut Mahfud MD yang dikutip oleh La Ode Maulidin mengungkapkan bahwa MK terkadang perlu membuat terobosanterobosan hokum untuk mewujudkan keadilan berdasar kepada hokum progresif atau dengan kata lain demi terwujudnya keadilan substantif. Hakim (konstitusi) harus bersifat adil dan mampu mengelaborasi pertimbangan hokum dengan fakta-fakta dalam persidangan dalam sebuah putusan. Sehingga, masyarakat di seluruh lapisan mudah memahaminya dan merasakan manfaat dari putusan tersebut (Maulidin, 2011).

Pada awalnya penyelesaian perkara Perselisihan Hasil Pemilihan Umum Kepala Daerah (PHPUKada) dijajaran pengadilan di tingkat bawah relatif rentan dengan tekanan politik, terutama ketika 
kekuatan politik di pusat ikut bermain memasuki ruang-ruang pengambilan keputusan pengadilan, acapkali hakim di pengadilan umum kurang memiliki kompetensi dan kecakapan untuk memahami dan menguasai dengan cepat sejumlah persoalan dan regulasi menyangkut Pemilihan Umum Kepala Daerah (Pemilukada). Hal ini berbeda dengan MKRI yang konsen dalam proses PHPU sehingga minimal memiliki perspektif visi dan wawasan yang lebih luas. Selain itu, dengan penyelesaian PHPU Kada di MKRI akan memindahkan dan mengubah konflik horizontal yang perpotensi anarkis dan penuh tekanan massa di daerah menjadi konflik elit dan sengketa hukum dilembaga peradilan (Artha, 2018).

Lahirnya MKRI diperuntukkan untuk mengatasi semua permasalahan dalam penyelesaian sengketa hasil PHPU Kada sebagaimana diuraikan diatas. Sejak diberikannya kewenangan dalam menyelesaikan PHPU Kepala Daerah, MK melalui putusan-putusannya melakukan berbagai terobosan hokum yang menjaga agar Pemilu tetap terlaksana secara demokratis sesuai amanar konstitusi (Hamdan Zoelva, 2013:3). Terobosan hukum yang dikeluarkan oleh MKRI cukup berpengaruh dalam meredam gejolak yang terjadi di daerah akibat ketidakpuasan dari pihak tertentu terkait hasil PEMILUKADA. Konflik horizontal yang terjadi akibat penyelesaian PHPUKada yang dilaksanakan oleh lembaga peradilan di tingkat peradilan tinggi acapkali terjadi, terlebih antara petahana yang mencalonkan diri kembali tentu sudah lama mempunyai hubungan baik dengan forum komunikasi pimpinan daerah yang salahsatu unsurnya adalah pimpinan pengadilan. Anggapan ketidaknetralan selalu menjadi perbincangan masyarakat meskipun sebenarnya pradilan tinggi sudah berusaha netral dalam memberikan putusan terkait PHPUKada.

Oleh karena itu, ketika wacana mengembalikan penyelesaian PHPUKada kembali ke Pengadilan Tinggi bergulir dan menjadi perbincangan hangat di berbagai kalangan, banyak pihak yang tidak setuju terhadap gagasan tersebut. Semua mafhum bahwasanya problem yang cukup rumit adalah penyiapan bahan- bahan dalam berperkara yang relatif memerlukan biaya oleh pemohon maupun termohon, namun ini adalah masalah administratif yang masih bisa dicarikan jalan keluarnya. Bahwa memberikan kepercayaan dan legitimasi kepada MKRI dalam penyelesaian PHPU 
Kada adalah sebuah kebutuhan di tengah krisis kepercayaan terhadap lembaga peradilan. Namun demikian sejumlah putusan MKRI pun patut dikritisi dalam rangka turut serta untuk mengawal MKRI tetap ada dalam roh dan wibawanya.

Sebagaimana telah dipaparkan di atas, wewenang Mahkamah Konstitusi sebagaimana diatur Undang-Undang Nomor 24 Tahun 2003, Pasal 10 ayat (1) huruf $d$, yang putusannya final dan mengikat untuk memutus perselisihan hasil pemilihan umum. Sebagai tindak lanjut perubahan paradigma Pemilihan Kepala Daerah (Pilkada) menjadi Pemilihan Umum Kepala Daerah (Pemilukada), maka Undang-Undang Nomor 12 Tahun 2008 Pasal 236 C telah memindahkan kewenangan penyelesaian PHPU Kada dari Pengadilan Negeri dan Tinggi ke Mahkamah Konstitusi (Artha, 2018).

Dalam konteks wewenang MKRI dalam penyelesian PHPU Kada, terdapat dua pandangan yang selama ini berkembang. Pandangan pertama, salah satunya yang dianut oleh mantan hakim konstitusi H.A.S Natabaya, bahwa MKRI hanya berwenang memutus perkara dengan objek hukum "hasil penghitungan suara" sebagaimana dimaksud MKRI benar-benar mempengaruhi penentuan pasangan calon untuk masuk putaran kedua atau menjadi calon terpilih. Jika tidak berpengaruh signifikan, maka MKRI tidak berwenang mengadili.

Pandangan pertama ini, juga beranggapan sikap MKRI yang dinilai sebagai terobosan hukum untuk menjadikan sejumlah alasan kualitatif seperti politik uang, mobilisasi Pegawai Negeri Sipil (PNS), pelanggaran Daftar Pemilih Tetap (DPT) sebagai pintu masuk untuk mempengaruhi penghitungan suara. Pendeknya, pemohon wajib membuktikan melalui penghitungan yang benar menurut pemohon bahwa penghitungan termohon salah. Tidak ada urusan dengan hal-hal di luar itu. Barangkali itulah yang menjelaskan kenapa MKRI pada kepemimpinan sebelumnya tidak pernah merekomendasikan pembatalan pasangan calon atau pemilu ulang karena alasanalasan tanpa pemungutan suara.

Pandangan kedua, menyatakan bahwa MKRI dapat mempertimbangkan dan menilai apakah proses penyelenggaraan Pemilukada tersebut telah berlangsung sesuai dengan asas LUBERJURDIL. Hal ini dapat dilihat apakah penyelenggaraan Pemilukada terdapat pelanggaran yang serius baik pelanggaran administrasi dan pidana yang 
bersifat terstruktur, sistematis dan masif sehingga mempengaruhi hasil penghitungan suara (Zoelva, 2016).

Pelanggaran sistematis adalah pelanggaran ini benar-benar direncanakan secara matang (by design), pelanggaran terstruktur adalah pelanggaran ini dilakukan oleh aparat struktural baik aparat pemerintah maupun aparat penyelenggara pemilu secara kolektif bukan individual sedangkan pelanggaran masif adalah dampak dari pelanggaran ini sangat luas dan bukan sporadis.

Hukum yang progresif tidak menerima hukum sebagai institusi yang mutlak dan final, melainkan sangat ditentukan oleh kemampuannya untuk mengabdi kepada manusia. Dalam konteks pemikiran itulah, hukum selalu ada dalam proses untuk terus menjadi. Hukum adalah institusi yang secara terusmenerus membangun dan mengubah dirinya menuju kepada tingkat kesempurnaan yang lebih baik. Kualitas kesempurnaan ini bisa diverifikasikan ke dalam faktor keadilan, kesejahteraan, kepedulian kepada rakyat dan lain sebagainya. Inilah hakikat hukum yang selalu dalam proses menjadi (law as a process, law in the making). Hukum itu tidak ada untuk diri sendiri, tetapi hukum itu untuk mengabdi kepada manusia.
Selain itu hukum yang progresif mengajarkan bahwa hukum bukanlah raja, tetapi alat untuk menjabarkan dasar kemanusiaan yang berfungsi memberikan rahmat kepada dunia dan manusia. Hukum yang progresif tidak ingin menjadikan hukum sebagai teknologi yang tidak bernurani, melainkan suatu institusi yang bermoral kemanusiaan (Rahardjo, 2006).

Oleh karena hukum progresif dinilai sebagai salah satu alat untuk memberikan rasa puas pada diri manusia dan kemanfaatan bagi semua. Prinsip keadilan dan kepastian hukum tidak diabaikan dalam aliran progresif, justru keadilan dan kepastian hukum yang mengedapankan nilai-nilai kemanusiaan yang memang diutamakan dalam aliran hukum progresift tersebut.

Pemikiran hukum progresif dalam setiap putusan MKRI sebenarnya sejalan dengan tujuan hukum sebagai mana penulis jelaskan diatas, yakni kepastian, keadilan dan kemanfaaatan yang berorientasi pada nilai-nilai kemanusiaan.

Hukum progresif ditandai dengan 4 (empat) ciri utama yaitu hukum untuk manusia bukan manusia untuk hukum, menolak status quo dalam berhukum, hukum tertulis memiliki keterbatasan dan reduksionis dan memberikan 
perhatian besar terhadap peranan perilaku manusia dalam hukum. Dengan ciri khasnya tersebut penafsiran hukum yang progresif tidak lagi menjadikan teks sebagai sesuatu yang otonom dan independen. Penafsiran hukum lebih mengandalkan spirit nilai keadilan yang substantif dari pada keadilan prosedural atau keadilan berdasarkan teks hokum (M. Ali, 2016).

Nilai substantif dalam pemikiran hukum progresif yakni mengedepankan isi dan hasil serta manfaat yang nanti akan dinikmati manusia sebagai sebuah nilai yang tinggi dalam mencapai tujuan hukum sebagaimana yang diharapkan oleh masyarakat. Dengan demikian sejak sekarang hingga masa yang akan datang setiap putusan MKRI khususnya dalam menyelesaikan PHPUKada harus bahkan wajib untuk lebih mengutamakan nilai substantif melalui pemikiran dan putusan yang progresif sehingga tercapai keadilan, kepastian, kemanfaatan dan kesejahterann bagi seluruh rakyat Indonesia.

\section{SIMPULAN}

Penyelesaian sengketa PHPUKada yang dilakukan oleh MKRI merupakan suatu solusi yang dianggap mampu menyelesaikan persoalan hasil pemilihan umum dan pemilihan umum kepala daerah, mengingat persoalan sengketa PHPU merupakan salah satu kewenangan yang dimiliki oleh Mahkamah Konstitusi sebagaimana diatur dalam UUDNRI Pasala 24 C serta pada UUMK. Putusan MKRI yang diistilahkan progresif merupakan terobosan hukum baru yang dilakukan untuk menyelesaikan segala persoalan terkait PHPUKada di Indonesia secara cepat, final dan mengikat.

\section{DAFTAR RUJUKAN}

Ali, M. (2016). Mahkamah Konstitusi dan Penafsiran Hukum yang Progresif. Jurnal Konstitusi, 7(1), 67-90.

Ali, M. M., Rachman, I. N., Wijayanti, W., Putranto, R. T. J., Anindyajati, T., \& Asih, P. G. (2016). Tafsir Konstitusional Pelanggaran Pemilukada yang Bersifat Sistematis, Terstruktur dan Masif. Jurnal Konstitusi, 9(1), 189-230.

Artha, I. G. P. (2018). Perselisihan Hasil Pemilukada: Putusan Mahkamah Konstitusi dan Implikasinya dalam Penyelenggaraan Pemilukadale. Www.Kpud-Pacitan.Go.Id.

Maulidin, L. O. (2011). Analisis Putusan Mahkamah Konstitusi Dalam Menyelesaikan Perselisihan Hasil Pemilukada Ditinjau Dari Perspektif Teori Hukum Progresif (Kajian Terhadap Putusan Mk Atas Sengketa Hasil Pemilu Kepala Daerah Jawa Timur Dan Putusan Mk Dalam Perkara Perselisiha. Jurnal Konstitusi, 4(1), 115100. 
Putusan Mahkamah Konstitusi No.45/PHPU.D-VIII/2010 tentang Perselisihan Hasil Pemilukada Kabupaten Kotawaringin Barat.

Rahardjo, S. (2006). Membedah hukum progresif. Penerbit Buku Kompas.

Rahardjo, S. (2010). Penegakan hukum progresif. Penerbit Buku Kompas.

Undang-Undang Dasar Negara Republik Indonesia Tahun 1945

Undang-Undang Nomor 24 Tahun 2003

Tentang Mahkamah Konstitusi

Zoelva, H. (2016). Problematika Penyelesaian Sengketa Hasil Pemilukada oleh Mahkamah Konstitusi. Jurnal Konstitusi, 10(3). 